\title{
An insight into a digital human as a thinking human being
}

\author{
Ekaterina Prilukova $^{1 *}$, Elena Evsina ${ }^{1}$, George Kwiatkowski ${ }^{2}$, and Svetlana Nestertsova ${ }^{1}$ \\ ${ }^{1}$ South Ural State University (national research university), 454080, Chelyabinsk, Russia
}

\begin{abstract}
Human nature and its future sound specially when the human mind penetrates the secrets of the universe, claiming the role of its constructor. The present world is characterized by a huge number of innovations, including the global distribution and introduction of information technique and technology. Digital technology raises the question of "improving" a person and the formation of a posthuman. Virtual and augmented reality, cloud services, artificial intelligence and neurocomputing, Blockchain technology, Internet of things, etc., created by new technique and technologies significantly transform not only the industry as the basis of any society, but also all spheres of society. Human consciousness captures new technique and technology and at the same time begins to be constructed by them. Nevertheless, the greatness of a person is determined by the presence of mind, although more and more often there is talk about the intelligence of "thinking" machines that can replace a person.
\end{abstract}

\section{Introduction}

Human nature and its future is one of the topics that has been discussed for a long time. It acquires special significance today, when the human mind seeks to penetrate the secrets of the universe and man. The creative potential of man, distinguishing him from others in the world and accompanying his work, knows no boundaries. However, the man himself remains an unsolved problem with many unknowns.

The world is dynamic and has a huge number of innovations claiming the status of tools for its constant transformation. These innovations include the global distribution and introduction of information technique and technologies, leading to major changes in society. As a result of human activity, digital technologies unlimitedly expand human capabilities and at the same time "invade" his body and consciousness at a completely new level - the level associated with the technologies of "improving" a person $[1,2,3]$. Cloud services, blockchain technology, Internet of things, artificial intelligence, neurocomputing, etc. radically change the actual reality, making it all the more artificial. New technique and technologies are not only traced in the human mind, but also allow it to be constructed. Human consciousness, viewed from various methodological approaches, remains a less solved problem in science. Therefore, it becomes the main "theater of operations" of battles for the future in the present, including

\footnotetext{
*Corresponding author: prilukova74@gmail.com
} 
the possibility of constructing a different social reality of man. If originally it was a question of biological improvement [4], then today the scientists discuss the possibility of the man's moral improvement $[5,6]$. An example of the use of technique and technologies to influence and change the man's consciousness is the modern mass media. It has assumed the functions of the creator of a new reality and the general designer of the picture of the world [7]. Thanks to its activity, the emotional component is enhanced by its comprehension and the value of rational-critical thinking decreases. However, man is a thinking being, although today it is more and more a question of the intelligence of "thinking" machines capable of replacing man. This is due to the development of powerful computers that led to the emergence of neural networks. Although artificial intelligence is not yet able to recognize itself as a person, nevertheless, it is already to some extent "rebelling" against man. Therefore, it is important to constantly turn to the understanding of man as a thinking being.

\section{Formulation of the problem/ problem}

To show the possibility of applying B. Pascal's provisions about a person to the analysis of modernity.

\section{Research methods}

Principles of the methodological hermeneutic standard.

\section{Analysis and discussion}

Authors who write about B. Pascal's works in Russia usually say that he is one of the famous people, although there are not so many works in Russian science about Pascal- the thinker. Physicists, mathematicians, and even philologists write about him rather than philosophers, although "the Pascal-scientist is inseparable from the Pascal-philosopher and even often confuses Pascal-Christian" [8]. Works about Pascal are controversial, ranging from admiration of "the great man" [9] to sharp criticism of the "wonderful person" [10]. This is not surprising, because his work is paradoxical and the paradoxes are due to the style of thinking of his time. In the history of science, the 17 th century appears as a century of parting with the tenets of the Middle Ages and appeals to the direct study of reality by a thinking subject (person). At the same time, the years of B. Pascal's life and creative work are the years of non-acceptance the discoveries of the "indisputable truth" in science and "preservation in the ordinary consciousness of superstition and prejudice" [11]. In the Russian historical and philosophical tradition the idea of the need to oppose R. Descartes and B. Pascal was formed and dominated for a long time. It is remarkable that this tradition was manifested not only in the analysis of the specific content of their creative works, but also in the description of personal characteristics. The first usually represents rationalism, intuition, and the deductive method as tools for perseveringly seeking the truth; a confident and knowing his role in the science balanced person. The second refers to mysticism, intuition, and the inductive method; a restless and doubting thinker, experiencing for the imperfection of man and defending his case in "battles" for the truth. Italicized words emphasize opposing lines. For the sake of justice, we find examples that make it possible to doubt the necessity of such oppositions.

R. Descartes believed that although feelings never deceive us, there are people who make mistakes. However, "I think, therefore I exist" [12] is the first principle of philosophy. Neither the mind nor the feelings are absolutely reliable. Only the man's own existence as a thinking being is absolutely certain. Descartes's man does not exist outside of thought. The same 
provisions are also found in B. Pascal, who asserted that "the initial concepts are cognized by feeling, the theorems are proved by inference; both in that and in other knowledge we can be sure, although they are achieved in different ways. And if the mind requires the proof of initial concepts from the heart in order to agree to separate them, it will be as ridiculous and useless as if the heart required the mind to feel all the theorems it proved to agree to accept them" [13]. It is clearly seen that R. Descartes and B. Pascal tried to defend and substantiate their point of view, in fact complementing each other. Striving for the free development of scientific knowledge, they turned to the human mind and experience, not only as a strictly scientific empirical method of natural science, but also as a life experience of the knowing subject himself. At the same time, each of them wanted to find universal rules for comprehending the world, knowing well enough all its complexity. That is why R. Descartes and B. Pascal were more like-minded people than opponents, and not because they were fascinated and "bewitched" by mathematics, devoting much of their scientific research. Despite the dominance of natural science, which began with the publication of the book by N. Copernicus "On the Rotation of the Celestial Spheres" (1543) and the desire of researchers to subordinate everything to it, Pascal tried to uncover the secrets of the foundations of human greatness through the presence of mind. Only man has mind and because of this, being a particle of the world, he (man) is able to master it and rise above it. Pascal, in all things tried to find the "thinking reed" in the infinite Universe and to demonstrate its ontological status the ability to think, as to reveal the essence of a person as a Man. That is why not only the rigorous logic of presentation and the demonstrative power of the arguments were important for him, but also simplicity, clarity, and emotional brightness in the message of the truth" [8]. Pascal recognized the man as the highest value, that even with his scientific style he showed concern for him. Whatever questions B. Pascal would address, they invariably acquired a philosophical character, even if they were treatises on physics and mathematics, reflections on faith and writing, both official letters and letters to his close friends. This is explained by the fact that his work on man is devoted to Man himself. Giving all his strength to science, which "was not only his" first thought", but also an all-consuming passion, the only purpose of life" [8] from your age. Pascal formulated a "universal rule" of scientific research, the meaning of which is the need to accept only what "seems clear and distinct to feelings or reason depending on the sphere of competence of one or the other" [13]. Man is so complex that, in his desire to understand the world, he turns either to thoughts, or to his mind. In fact, here is the nature of man. Pascal emphasizes its complexity due to the fact that a person is rational at the same time irrational. So "the main lack of reason consists in its selfishness, susceptibility to all kinds of influence: from the side of feelings, passions, imagination, personal and social, interests, etc." [8], the subtle mind relies on sensual intuition. $\mathrm{n}$ this universal mind of the thinker "grabbed" the content of his time - the time of birth of a new man, who relies on the mind and puts him at the forefront. However, he doubted his priority over feelings, because the mind is strong and weak at the same time. By this he anticipated the state of man of the present, when the consumption of things begins to dominate his own human being. Nevertheless, Pascal deeply believed in man and valued him, believing that he was great and that his greatness was taking place "even in his passions" [13]. As a result, a person begins to need something that will allow him to find a way out of the state of loss of his stay in the world foundations. Such a thing in Pascal's understanding of man was supposed to be religious faith, which he tried to defend.

Special attention should be paid to Pascal's consideration of the man's world comprehension. As being too contradictory himself, his nature "does not know movement in a straight line; it has its ebbs and flows" [13]. At the same time, despite this inconsistency, a person must be aware of his purpose and his "surprising reason for errors - the war between feelings and reason" [13]. Modern studies on human nature, one way or another, point out this 
contradictory complexity [14. 15]. B. Pascal's man is capable and must be constantly thinking (authors' italics), because "all our dignity lies in thought. That is our greatness, not in space and time, which we cannot fill. Let us try to think as it should be: this is the basis of morality" [13]. Although the head is necessary for a person and it is impossible to imagine it without thought, the mind is inclined to be mistaken - it never absolutely wins - it needs feelings, but should not obey them, they complement its ideas about the world. However, it is not always possible to keep and maintain this balance nowadays.

Information replicated by media, serving as the basis of knowledge about the world, is increasingly visualized and supplied with the help of image-products of the screen. The representation of the world is carried out by new sign-symbolic systems created in accordance with the logic of a digital code and combining simultaneously visualized verbal and nonverbal components of communication. It is important to emphasize that a digital code is nothing more than a specific sign-symbolic system created by programming languages. From the point of view of the development of epistemological, neuro-cognitive and psychological processes, screen media is fundamentally different from printed and radio in that it "owns" image, which in the conditions of modern perception of the world is a certain "message" about it [16]. The image of the screen becomes an integral feature not so much of fixation as the construction of everyday life, making it artificial and programmable. The visual picture of the world, due to its nature (bright, emotionally-colored, "alive") is formed much faster and remains in the consciousness as something unstable, capable of changing very quickly. The world turns into what is "here and now" on the screen - there is no familiar understanding of space and time in it. Space and time of simulation are formed, allowing to continuously interpret and reinterpret the picture of the world. Moreover, Internet technologies of communication provide an opportunity for its participants to be co-participants and co-authors of this picture. There is a borderless social and technological expansion of human capabilities [16], affecting the formation and development of personality in the context of new - Artificial (virtual and augmented) - realities. In these fundamentally different realities created by the avalanche-like streams of endless screen images, a person finds himself in a situation of meeting with something like an "invisible plane" - he is engaged in the world, but is unable to understand it and there is no time to think about it - the world is predetermined. However, "meaningful meditation" is the essential characteristic of a person and the highest form of manifestation of his intellect [17]. The refusal of hard work of thought creates favorable conditions for the formation of all sorts of manipulating public and individual consciousness practices [18].

In the first quarter of the XXI century, we return to comprehension the world and its description not only on the basis of information provided by mind. We are partly forced not to trust it, because ideas about the achievements of modern science based on post-non-classical rationality are probabilistic in nature. Modern science "works" directly, not only with objects of nature, but also with their mathematical and computer models, which are not reality, they are its analogue, a kind of similarity [19]. So "the microcosm needs to be observed by its actions through highly-perfect experimental techniques. However, it will no longer be the subject of our immediate sensory perception. Here the scientist should abandon the idea of the direct connection of the basic concepts on which he builds his science, with the world sensory perceptions ... Our complicated experiments are not nature in themselves, but changed and transformed under the influence of our activity in the process of research ... Consequently, here we also come up against the insurmountable limits of human knowledge" [20]. Thus, the "eye" of an optical (or light) microscope "speaks" significantly more about the structure of the cell than the human eye, and the "eye" of an electronic one - even more than light, because electrons make it possible to see small parts traversed by light rays. Partly doubting the activity of the mind, we begin to appeal to the senses in understanding the world. The 
hypertrophied "all-seeing and omnipresent eye" of electronic media creates favorable conditions for constructing a picture of the world through the senses and, above all, visual perception. It is difficult not to trust, let us remember at least the Russian proverb "it's better to see once". The eye in the conditions of modernity turns into the main supplier of information about the world - up to $80 \%$ of all information falls on it [21]. It confidently "grasps" and "reads" the signs and symbols enclosed in the images of the screen, delivering them to the brain, where the received information is processed. Information from the eye can be joined by information from other senses during the perception of the screen image.

Visual images influence not only the speed of "reading" and perception, but also the entire nervous system of a person. The images presented on the screen, due to their nature, are bright and focused on emotional reactions, rather than on comprehension, easily penetrate into the consciousness, being fixed in it. They "absorb" the person and rule over him, assuming the functions of the creator of the picture of the world and his life, offering their picture of the world. Person is freed from the need for thinking, he "plunges" into the world of screen images, perceiving what is happening as a "picture" carrying values and traditions in a form compressed in time and space. As an example, news with short message-pictures, advertising stories and innocuous, at first glance, likes. Gradually, images replace and replace reality, generating its simulation that is much brighter and more attractive than the most actual reality [22]. The world on the screen becomes a model for imitation in the real world. Visual perception gives us the illusion of immediate presence-perception, providing the possibility of "direct" "reading" the text. However, this "reading" follows the prescribed rules: the presence of a certain scenario of the plot, the camera's "eye" placed in a special way, the captured and mounted frames, color, light, etc. In perspective, this leads to a weakening of rational-critical thinking abilities [23]. Studies show that in the cerebral cortex, when "reading" images of a screen, neurons are excited, due to which an image of the displayed object appears in consciousness [24]. The logically connected basis of thinking and perception of the world in the images of the screen lead to the mastery of the world on the basis of the principle of the "kaleidoscope mirror". Consequently, instead of holistic picture of the world and its images and concepts connection there remains only collage, carrying individual "pictures" of reality [25]. The world begins to be perceived only by the "heart", when sensual-figurative thinking begins to dominate over the rational-critical and logical-conceptual. As a consequence, natural language is simplified and becoming an increasingly primitive new slang, hypertext is formed, plots are typed, mass standards and patterns are created not only of behavior, but also of thinking. As a result, the understanding of the nature of human knowledge as a way "of knowing the truth not only with the mind, but also with the heart" [13] becomes very relevant.

\section{Conclusion}

Obtaining and extracting information is carried out using images or simulacra. Their content is largely determined not only and not so much by what and how they are represented, but also by the intellectual potential that they are created by and the way they are perceived. The constructor of the world appears. We return to man and his "content", depending on the context of sociocultural reality. A person is the greatest and universal value: he is able to create. herefore, the methodological instructions of $\mathrm{B}$. Pascal are relevant in the conditions of modernity, when it comes to not just the formation of a new society, but also a completely new type of person - the post-human. Pascal's scientific work is multifaceted; it is distinguished by the breadth and depth of theoretical analysis, remaining methodologically mature and practically applicable after centuries. Blaise Pascal returns us to the comprehension of man through the comprehension of the thought of man. 


\section{References}

1. N. Agar, Truly Human Enhancement: A Philosophical Defense of Limits (The MIT Press, Boston, 2013)

2. I.Yu. Alekseeva, V.I. Arshinov, V.V. Chekletsov, «Tekhnolyudi» protiv «postlyudei»: NBIKS-revolyutsiya i budushchee cheloveka, Voprosy filosofii, 3, 12-21 (2013).

3. B.G. Yudin, Texnonauka $i$ «uluchshenie» cheloveka, Epistemology \& Philosophy of Science, XLVIII(2), 18-27 (2016).

4. B.G. Yudin, Chelovek kak ob "ekt texnologicheskix vozdejstvij, Chelovek, 3, 5-20 (2011)

5. T. Douglas. Moral Enhancement, Journal of Applied Philosophy, 25(3), 228-245 (2008).

6. K. Raus, F. Focquaert, M. Schermer, M. J. Specker, S. Sterckx, On Defining Moral Enhancement: a Clarificatory Taxonomy, Neuroethics, 7 (3), 263-273 (2014)

7. E.G. Prilukova, The shadows of the power in a modernity, SGEM 2016. 3 International multidisciplinary scientific conference on social sciences and arts. 24-26 August, 2016. Albena, Bulgaria. Sofia: STEF92 Technology Ltd., "Alexander Malinov" Blvd, 51, 925-928 (2016)

8. G.Ya. Strel`czova, Paskal i evropejskaya kul 'tura (Respublika, Moscow, 1994)

9. B. Tarasov, «My`slyashhij trostnik». Zhizn` $i$ tvorchestvo Paskalya v vospriyatii russkix filosofov i pisatelej (Yazy’ki slavyanskix kul’tur, Moscow, 2009)

10. S.V. Sinyakov, E.F. Slastenko, Problema mira i cheloveka v filosofii B. Paskalya $i$ G. Skovorody', Visnik NAU. Seriya: Filosofiya. Kul'turologiya, 2(20), 29 (2014). Information on https://er.nau.edu.ua:8080/handle/NAU/14643.

11. Yu. Ginzburg, Mysli o glavnom (Izd-vo im. Sabashnikovykh, Moscow, 1995)

12.R. Dekart, Vozrazheniya nekotorykh uchenykh muzhei protiv izlozhennykh vyshe «Razmyshlenii» s otvetami avtora, T. 2. (Mysl', Moscow, 1994)

13. B. Paskal', My sli (Izd-vo im. Sabashnikovy`x, Moscow, 1995)

14. S.A. Lebedev, Ontologiya cheloveka, Chelovek, 1, 15-29 (2010)

15. S.A. Smirnov, Chelovek v mire mirov (k voprosu o neklassicheskom filosofstvovanii o cheloveke), Filos nauki, 3, 121-126 (2015).

16. E. Faiola, A.E. Voiskunskii, N.V. Bogacheva, Chelovek dopolnennyi: stanovlenie kibersoznaniya, Voprosy filosofii, 3, 147-162 (2016)

16. T.A. van Deik, Yazyk. Poznanie. Kommunikatsiya (Progress, Moscow, 1989)

17. M. Xajdegger, Razgovor na proselochnoj doroge (Vy`sshaya shkola, Moscow, 1991)

18. S.A. Zelinskij, Manipulirovanie massovy`m soznaniem. (Altaspera Publishing \& Literary Agency Inc., Canada, 2014)

19. M. Vartofskij, Modeli. Reprezentaciya i nauchnoe ponimanie (Progress, Moscow, 1988) 1953).

20. V. Geizenberg, Filosofskie problemy atomnoi fiziki (Izd-vo inostr. lit., Moscow,

21. S. Maharjan, M. Gold Jason, R. Sekuler, Memory and learning for visual signals in time and space Atten Percept Psychophys, 79, 1107. Information on https://doi.org/10.3758/s13414-017-1277-x. (2017). 
22.Zh. Bodriiyar, Simulyakry i simulyatsii (per. s fr. A. Kachalova) (Izdatel'skii dom «POSTUM», Moscow, 2015)

23. N. Mirzoeff, Introduction to Visual Culture (L.- N.-Y. 1999) 3-4.

24. G. Rizzolatti, L. Fadiga, V. Gallese, L. Fogassi, Premotor cortex and the recognition of motor actions, Cognitive Brain Research, 3, 131-141 (1996)

25. F. Deskola, Po tu storonu prirody i kul'tury (Novoe literaturnoe obozrenie, Moscow, 2012) 